\title{
Adopting Agricultural Marketing Approach for Improving Agricultural Sector Performance in Nigeria
}

\author{
Dr. Nebo, Gerald Nwora ${ }^{1}$, Prof.Ejionueme Ngozi ${ }^{2}$ \\ ${ }^{I}$ Department of Marketing, Enugu State University of Science and Technology, Enugu State, Nigeria. \\ ${ }^{2}$ Department of Marketing, Enugu State University of Science and Technology, Enugu State, Nigeria.
}

\begin{abstract}
In spite of huge government's efforts at improving agriculture in Nigeria, the sector still suffers unabated dwindling performance. The concern of this study was how to improve the Nigerian Agricultural sector performance from the marketing perspective.The objectives of the study include: to determine significant problems of marketing agricultural products in Nigeria; to ascertain the influence of products on agricultural sector performance in Nigeria; to assess the influence of distribution on agricultural sector performance in Nigeria and; to determine the influence of price on agricultural sector performance in Nigeria. Survey research design was adopted for this study. A structured questionnaire was used to collect data from a sample of 250 agricultural marketers comprising of farmers and farm products' distributors in South-eastern Nigeria. The reliability of the research instrument was ascertained using Cronbach Alpha test which yielded 0.81 coefficient. Hypotheses were tested using Principal Component and Regression Analysis. Findings show that production, distribution and pricing-related factors were the most significant problems of agricultural marketing; and that products, distribution and price were marketing variables likely to significantly improve agricultural sector performance in Nigeria. It was recommended that government, entrepreneurs who are non-governmental organizations and large scale farmers should provide effective solutions to those major variables identified in this study ashindrance to agricultural marketing and also capitalize on those marketing variables that have significant influence on agricultural performance in Nigeria to improve the sector.
\end{abstract}

Keywords: Agriculture, Agricultural Marketing, Products, Price, Distribution, Performance,.

\section{Introduction}

The need to promote agriculture lies in its importance to nation-building all over the world. Agricultural sector performance particularly through improved productivity is one of the major ways of reducing poverty in developing countries. Improvements in agricultural productivity and performance have been identified as strong correlate of poverty reduction. Thirstle et al (2013), for example, argue that improved agricultural performance is associated with reduced incidences of poverty. Similarly, research by Food and Agricultural Statistics (2004) shows that poverty reduction has occurred most rapidly in areas where significant productivity gains in agriculture have occurred (e.g. East Asia) while poverty has increased in both proportion and number in sub-Saharan Africa where there is staggering growth in agricultural productivity and performance.

Agricultural sector in many countries has been described as the engine of economic development (Food and Agricultural Statistics, 2004). History consistently shows that no country has ever successfully industrialized without first achieving significant improvements in agricultural performance. This is particularly true for Europe, North America, Japan and newly emerging industrialized countries of Asia where industrialization has been very clearly agriculturally led (Timmer, 1988)

However, in Nigeria the reverse is the case.The sector has not been performing as expected judging from continuous decline in its contribution to the nation's GDP and foreign exchange earnings. Prior to the discovery of crude oil, the sector provided the much needed foreign exchange, income, food, fiber, fuel, employment and raw materials for our growing industries. However, following the emergence of petroleum as the main provider of the country's foreign exchange in early 1970s the attention of government shifted away from agricultural production resulting in progressive decline in the percentage contribution of agriculture in the nation's economic development. In fact development economists have attributed the present economic predicament in Nigerian to poor performance of the agricultural sector and over reliance on one product which is crude oil as the major source of foreign exchange earner (Ojo, 2001). It is in realization of this fact that government of Nigeria is now strongly advocating improvements in agricultural productivity and diversification of the economic base from oil to non-oil products. Various attempts have been made by past and present government to improve agriculture but the sector has continued to record poor performance. Scholars have also made various contributions on how to improve 
agricultural sector performance but previous studies seem to concentrate more on improvements in agricultural production than agricultural marketing. Studies have equally shown that one of the major constraints to agricultural sector performance is poor attention given to agricultural marketing policies by government. Agricultural production and marketing are two sides of a coin, one cannot do without the other. Scholars warn that no meaningful progress would be realized in agriculture unless ready markets exist for what is produced. Research evidence shows that market access is strongly related to agricultural productivity (Kamara, 2004, Minten, 1999). This paper, therefore, differs from previous studies by providing insight on how to improve agricultural sector performance through strategic approach to marketing of agricultural products in Nigeria.

\subsection{Statement of the Problem}

Improvements in Nigerian Agricultural sector performance is possible if the right marketing strategies can be identified and adopted just like India, Taiwan, Korea, Brazil and Malaysia and other countries that share similar problems with Nigeria did in the past.With the disappointing contribution of agricultural sector to Nigeria's economic development; calls from various scholars on how to effectively improve agricultural productivity and performance have continued to receive a heightened attention.

Studies pointing marketing as a potent tool for organizational performance are tremendous, yet knowledge of how it can be used to improve agricultural sector in Nigeria appear shallow in the following ways:-

First, studies have identified marketing variables that can improve organizational performance, yet very few of these studies were undertaken to specifically apply to Nigeria's agricultural sector.

Secondly even among studies that try to identify marketing variables that influence organizational performance, reports of inconsistencies are wide. For example, McDaniel and Hise (1984) found that chief executives officers judge two of the 4Ps, price and products to be somewhat more important than the other two, place and promotion while LaLonde (1977) found product related criteria to be more important followed by distribution, price and promotion.

Similarly some scholars argue that agricultural sector performance can be improved if problems of marketing agricultural products can be identified and solved. A number of factors have been identified in previous studies as problems of marketing agricultural products, however, the context within which these studies are carried out are known to influence the significance of these problems in specific situations. Agricultural marketing problems identified by past studies in other countries or regions may not be exactly the same with that of Nigeria. Therefore it is important to identify these agricultural marketing problems in the Nigerian context and categorize them according to their level of significance.

In addition, the quantum of past research studies seem to focus more attention on agricultural production inputs as a way of improving agricultural sector performance in Nigeria relative to agricultural marketing. There seems to be a conspicuous lack of knowledge of marketing approach to promoting agricultural sector performance in Nigeria. From previous studies, it appears that there is no robust agricultural marketing policy in Nigeria. Hence there is the need to direct government in crafting policies that are likely to improve agricultural sector performance in Nigeria from agricultural marketing perspective. These apparent paucities and knowledge gaps in the literature are the problems necessitating this study.

\subsection{Objectives of the Study}

The objectives of the study are:-

1. To determine significant problems influencing marketing of agricultural products in Nigeria.

2. To ascertain the influence of product on agricultural sector performance in Nigeria

3. To assess the influence of distribution on agricultural sector performance in Nigeria.

4. To determine the influence of price on agricultural sector performance in Nigeria.

\subsection{Research Hypotheses}

$\mathrm{H}_{01}$ : Production, distribution and price are not significant problems of agricultural marketingin Nigeria

$\mathrm{H}_{02}$ : Product does not significantly influence agricultural sector performance in Nigeria

$\mathrm{H}_{03}$ : Distribution does not significantly influence agricultural sector performance in Nigeria

$\mathrm{H}_{04}$ : Price does not significantly influence agricultural sector performance in Nigeria

\subsection{Conceptual Meaning of Agricultural Marketing}

\section{Review Of Related Literature}

Before conceptualizing the term 'Agricultural Marketing', it would be ideal to first examine the concept in its separate word forms i.e. "Agriculture" and "Marketing". 
Adopting Agricultural Marketing Approach for Improving Agricultural Sector Performance in Nigeria

The term agriculture is derived from two Latin words "Ager" and "Cultura." Ager means "land"and "Cultura" means "Cultivation". Put the two words together, agriculture means land cultivation i.e. tilling the soil and preparing it for planting of corps (Uturu, 2002). However in this modern day farming, agriculture means more than land cultivation for crop planting. Modern agriculture could be defined as the production of crops and rearing of animals for the purpose of producing food for man's use and raw materials for industries (Ejionueme and Nebo, 2014). Agriculture therefore involves the following activities: cultivation of land for the production of crops; rearing of animals for the production of food and raw materials; partial processing of farm products, storage and preservation of farm products.

The term "Marketing," on the other hand, have been defined in various ways by different scholars. Some of the early definitions have been criticized as too narrow to represent the true scope of modern marketing. For example, in 1960, the Committee of Definitions of the American Marketing Association (AMA) defined marketing as "the performance of business activities that direct the flow of goods and services from producer to the consumer". Although, this definition of marketing did reflect a more or less general consensus among marketers, there are three major grounds for this criticism. First, the definition implies that marketing activities are relevant or necessary only after the goods or services to be marketed have been produced. This is misleading.Modern marketing is no longer limited to this passive role of directing the flow of goods and services; it now plays an active role in the determination of what kinds of goods and services will be acceptable to consumers and therefore, what attribute should be incorporated in the product. These activities precede physical production of goods and services.

Second, this definition restricts the performance of marketing functions to business enterprises, a view which most marketers are unwilling to accept today. The modern view is that marketing is relevant to any individual or organization, whether business or non-business which seeks any form of patronage. In this sense, religious organizations which seek to enlarge their congregations can and do resort to marketing in the same way that profitoriented enterprises do. Similarly, individuals and non-business bodies in search of assistance, recognition or patronage can appeal to marketers for professional assistance.

Third, the definition by the American Marketing Association ignored the basic fact that marketing activities may still be performed in respect of products that have already been sold. Examples of such after-sale services are; assisting the buyer to transport the products (delivery), providing him with installation, maintenance and repair services and assisting him to overcome whatever challenges he may encounter in deriving maximum benefits from his purchase. The purpose of these activities is to create a satisfied customer so that himself, his friends, associate and admirers may be encouraged to patronize the marketer in future.

Modern scholars stress consumer satisfaction, universal application and the exchange process in their definitions of marketing. For example Kotler (1980) defined marketing as human activity directed at satisfying needs and wants through the exchange process. Onyeke and Nebo, (2012) submit that marketing is the anticipation, identification and satisfaction of human needs through the exchange process. It is according to Nebo (2015) individual and organizational activities directed at sensing and serving the customers' needs and expediting exchanges in order to achieve the individuals and organisations' objectives. Marketing is also seen as the process of planning and executing the conception, pricing, promotion and distribution of ideas, goods and services to create exchange that will satisfy individual andorganizational objectives (Zikmund and D'Amico, 1993).

The above definitions show thatmodern marketing isconcerned with the performance of the activities that enable individuals or organisations to find what people need and satisfying them through the exchange process. Marketing is not just buying and selling or distribution of goods and services already produced. It is different from selling based on the fact that it identifies and anticipates consumer needs before production.

Marketing activitiesprecede production by determining what the consumer needs and directing the production department accordingly. Marketing activities also go beyond exchange to ensure that consumers are satisfied with the products they have purchased. Marketing principles is applicable everywhere and in all organizations including agricultural sector.

Having conceptualizeAgricultureand Marketing, what then is agricultural marketing? The term agricultural marketing is simply the application of marketing concept in dealing with agricultural products. Agricultural marketing is the anticipation, identification and satisfaction of the needs of consumers in agricultural markets. It begins before production by determining what products consumers would need and continues after production by ensuring that what is produced are packaged, processed, stored, transported, standardized, graded, priced, promoted and made available to the consumers through various marketing channel members such as farmers, agents, wholesalers and retailers (Ejionueme and Nebo, 2014). 
It involves agricultural pre-production, production and post-production activities aimed at satisfying human needs. Agricultural marketing brings producer and consumers together for the exchange of agricultural products for money or some other valuables. Specifically, agricultural marketing helps to determine what agricultural products to produce, how to produce it and for whom to produce it and how to transfer what has been produced to the final consumers.

\subsection{Marketing Variables Likely to Influence Agricultural Sector Performance}

Certain marketing factors that have been empirically identified to influence performance of agricultural sectorinclude:

1. Problems that constrain agricultural marketing

2. Product

3. Price

4. Distribution

5. Marketing Promotion

Marketing communications or promotion are often not used by individual farmer to influence demand for agricultural produce because of their undifferentiated or homogeneous nature. Any promotional expenditure by one producer of a particular commodity will benefit another producer of the same commodity without paying a dime!. As a result, marketing promotions are excluded from this study. We examine each of the above variable in turn beginning from the problems that hinder agricultural marketing

\section{Problems that constrain agricultural marketing}

Various studies, both in developed and developing nations, have shown that problems of agricultural marketing can have significant influence on the performance of agricultural sector. The factors that are consistently mentioned in the literature as problems of marketing agricultural product can conveniently be grouped into three. These are: production, distribution and pricing -related problems (Ejionueme and Nebo, 2014, Uturu, 2002; Ugwuanyi and Ugwuanyi, 1999; Okuneye, 2012; Dayo et al, 2009, Kohl and Uhl, 2002).

Production -related problems. This refers to the problems related to the production of agricultural products. These are Land tenure system, soil fertility, flood, fire, irrigation, poor weather, pests and rodents attacks and lack of agricultural inputs such as capital, fertilizer, improved seedlings and modern farm technology.

Distribution-related problems. These are constraints related to transfer of products' titles amongst channel members or marketing logistics such as transportation, storage and market stall facilities that aid the movement of agricultural products from farm or ranches to market.

Price-related problems: These are problems related to pricing of agricultural produce such as high cost of production and distribution and farmers' inability to control prices due to perishable, homogeneous and seasonal nature of agricultural products.

\section{Agricultural Products}

A product is anything that the buyer acquires or purchases to satisfy a need or want. It is regarded as anything that can be offered to a market for attention, acquisition, use or consumption to satisfy a need or want (Armstrong and Kotler, 2005). It includes physical goods, services, ideas, places, persons and organizations. Consumers buy products in order to provide solutions to their problems or needs.

Agricultural products are industrial and household natural products which originate from farms, ranches, orchards, fields, vineyards and in the waters of oceans, lakes and rivers which have not undergone any serious manufacturing and processing (Ejionueme and Nebo, 2014). They can be described as goods in or near to their first stage of transformation (Gordon-Ashworth, 1984). It is a good or service for which the core benefits is largely undifferentiated. According to Brown (2005), agricultural products are those grown or raised from land while they remain in an unprocessed or partially processed state. Products that are harvested or fished from bodies of water are also agricultural products until they have undergone substantial transformation.Agricultural products are parts of primary commodities. One criterion of a primary commodity is the relative lack of differentiation among producers. Many scholars agree that modern marketing activities begin before production (Onyeke and Nebo, 2012; Armstrong and Kotler, 2005). This means that marketer's first task is to engage in research to identify the products that will meet the buyers' needs

Based on these, agricultural produce can be classified into six which are: foods, fibers, fuels, raw materials, pharmaceutical drugs/stimulants and ornamental or exotic products. By industrial standards they can be classified 
Adopting Agricultural Marketing Approach for Improving Agricultural Sector Performance in Nigeria

into subsectors as: livestock and meat, poultry, aquatic, fruits and vegetables, milk and dairy, grain, cotton and textile as well as tobacco subsectors (Ejionueme and Nebo, 2014).

Key agricultural product variables investigated in this study are: nature of the product, quality, standardization, grading, packaging and branding. Each of them is described below.

Nature of Agricultural Products

Agricultural products compared to manufactured products are highly perishable, bulky, homogeneous/ undifferentiated,raw /unprocessed, unstandardized in quality, difficult to predict production volumes, geographically concentrated, seasonal (Ejionueme and Nebo, 2014, Uturu, 2002; Kohl and Uhl, 2002).

- Highly perishable: Most agricultural products such as yam, cassava, fruits and vegetable do not have long life span. They deteriorate and spoil after a while some in a matter of a day or two and others such as rice, beans and cocoyam after some months. This situation affects the quality and volume of those products and constitutes a very serious challenge to agricultural marketing in Nigeria because of lack of power, preservative, processing and storage facilities.

- Bulky: When compared with manufactured products, agricultural products are bulky. This is because they come in raw state and most of them have moisture content and farmers do not reduce their sizes during harvest.For instance, plantain and palm-fruits are usually not reduced in sizes during harvest. Because of this, storage and transportation costs are usually high compared to their monetary values.

- Homogeneous: Despite quality variations, farm products in general are said to be similar, homogenous or largely undifferentiated in nature. This makes differentiation and branding efforts difficult thus, giving rise to difficulty in the application of advertising and other marketing promotion tools in selling the products. Buyers have little reason to prefer one farmer's product over another. Consequently, each farmer receives about the same price for the same quality of product. Individual farmers can do little to raise the general price level of their commodities, although some farmers with superior marketing skills do receive higher prices than others for similar-quality products. For instance, there are opportunities for farmers to add more value to their products, and this can be done by altering the production process to differentiate their products.

- Raw or Unprocessed: Agricultural products in their very nature have not undergone any serious processing. Because they are grown in the farm, they are natural and come in raw forms. Some of these produce require cleaning and some forms of processing before they are fit for human consumption.

- Unstandardized Quality: The quality of agricultural commodities varies from year to year and from season to season. During some years the growing conditions are such that the crop is generally of high quality. In other words, unfavourable conditions may prevail and the crops are of much lower quality. Farmers and food marketing firms rely on standardization and grading to sort and price farm products of differing qualities.

- Difficult to Predict Production Volume: Production of most agricultural products depends on weather conditions, pests, diseases and soil chemistry which are difficult to predict. As a result, farmers find it difficult to make a fairly accurate estimate of volumes of yields during the planting season.

- Seasonal:Some farms products are produced more or less continually all year round, for example, eggs and milk while others such as grains are seasonal and are harvested once each year. Their marketing challenges differs accordingly. For those that are harvested once a year (i.e highly seasonal produce), storage facilities, where they exist are used at near capacity during some part of the year and at other times they will be almost empty. In other words, excess supply exists during on-seasons and acute shortage exists during off-seasons.

- Geographically Concentrated: Although a variety of farm products is produced in all states, there is increasing geographic specialization of farm production due to climatic conditions and other natural environmental factors. Each region tends to specialize in the production of commodities for which its resource base is best suited.

Quality of Agricultural Produce: This refers to the sum of the attributes of a commodity that influence its acceptability and value to many buyers and hence the price they are willing to pay for it. It is also the ability of a product to perform as expected.

Standardization and Grading: Standardization describes uniform quantity, quality, type, size and weight of a product. It concerns the development and use of constant measures of quantity and quality of various goods. Standardization is a quality control measure to ensure that products are not adulterated. Grading is the actual sorting of a product according to established standards or yardsticks for easy identification and purchases.

Packaging and Branding. Packaging is the product's container or wrapper while branding is the act of identifying a product with a name, a sign, a symbol or design or a combination of these which is intended to distinguish the products or services of one seller from another. 


\section{Agricultural Prices.}

This is the value of a commodity or service expressed in monetary terms (Pride and Ferrel, 1995). It is the money paid or agreed in exchange for a product. Price and pricing decisions are variables in agricultural marketing. Even if all other aspect of agricultural marketing elements are right, with the wrong price neither the buyer nor the producer will be willing to engage in exchange transaction. Price determines demand and supply.

Owing to the homogeneity of agricultural products, prices are often determined by forces of supply and demand. Farmers take prices rather than fix prices. Similarly, prices fluctuate often due to seasonality of some agricultural products resulting in low prices during on-seasons and high prices during off-seasons. Storage, transportation, off-season planting, exporting, improved seedlings, processing and guaranteed minimum price are all effective strategies farmers can adopt to get better prices at harvest seasons (Ejionueme and Nebo, 2014).

Production and distribution costs, markups, discounts and competition are price variables investigated in this study.

\section{Distribution of Agricultural Products}

Distribution is the course taken in the transfer of title of a product from the first owner in this case the farmer to the last owner which is the consumer (Ejionueme and Nebo, 2014). All agricultural marketing efforts come to nothing unless products from the farmers' orchards, ranches or farms get to the consumers who need them. In performing the delivery functions, products and their titles pass through certain paths or routes from the producers to the consumers. These routes are called distribution or trade channels. Distribution function creates form, time, place and possession utilities to products. Geographical specializations are common in agricultural productions, therefore produce must be moved from the areas of surplus to areas of shortage using channel members and key logistics such as transportation, packaging and storage facilities. These facilities (storage and transportation) are key distribution variables investigated in this study.

Storage. This is a marketing function which entails the accumulation of agricultural produce from time to time in a storage house until they are needed by consumers. It helps agricultural marketers to hold excess produce during the harvesting seasons and protects the produce against adverse weather conditions.

Transportation. This is the movements of produce from where they are produced to where they are needed through various transportation modes such as trains, pipeline, trucks, air craft, vessels and ocean liners.

\subsection{Agricultural Sector Performance in Nigeria}

The term performance refers to the extent a person does a piece of work or an activity in an organisation (Akpala, 2003). Similarly; performance may be regarded as a task or operation seen in terms of how successfully it is performed or done (Nwosu, 2007). It is seen as the accomplishment of a given task measured against preset known standards of accuracy, completeness, cost and speed (Austine, 1996). Agricultural sector performance therefore refers to how well the agricultural sector has performed in its expectations or roles in the development process.

\section{Measures of Agricultural Sector Performance}

The key modes of agricultural sector performance assessment identified by scholars are objective or economic measures and subjective or non-economic measures (Dess and Robinson, 1984; Venkatra man and Ramanujann, 1986). Objective or Economic measures of agricultural sector performance are absolute figures of economic/financial measures such as Gross Domestic Product (GDP), index of agricultural output, agricultural exports as a percentage of total exports, percentage share of agriculture in total employment and average agricultural growth rate

The subjective measures on the other hand employ measures that are not quantitative or not based on absolute figures. They are based on agricultural sector's performance ratings by policy makers. This entails asking government agricultural decision or policy makers to rate how good or bad agricultural sector has performed against some yardsticks or criteria such as Gross Domestic Products, foreign exchange earnings, employment level, food provisions and so on.

\section{Assessment of Agricultural Sector performance in Nigeria and the Need for Promotion/Improvement.}

The roles of the Nigerian agricultural sector according to the Nigerian Agricultural Policy document (Federal Department of Agriculture 1988, Federal Department of Agriculture 2001) include provision of food for the growing population, foreign exchange earnings, employing a significant part of the labour force, provision of raw materials for industries and provision of income for farming households. 
Adopting Agricultural Marketing Approach for Improving Agricultural Sector Performance in Nigeria

The agricultural sector in periods immediately after independence in 1960 performed these roles so well that the regional developments witnessed during these period were linked directly to the sector. However since the era of oil boom in early 1970s, the sector has witnessed a tremendous decline in its contribution to national development. In fact the bad economic situations currently witnessed in Nigeria have been attributed to poor performance of the agricultural sector (Okumadewa, 1997)

Agricultural Performance in Food Production

Table 1 below shows Nigeria's food balance sheet. It highlights domestic food production, demand and short falls from 2004 to 2011.

Table 1. Comparison of Food Production and Demand with Shortfalls and Imports (Million Mt)

\begin{tabular}{|l|l|l|l|l|l|l|l|l|}
\hline Description & 2004 & 2005 & 2006 & 2007 & 2008 & 2009 & 2010 & 2011 \\
\hline Production & 86.70 & 89.25 & 93.35 & 95.64 & 98.74 & 100.41 & 102.12 & 103.86 \\
Food demand & 87.23 & 89.55 & 96.26 & 99.03 & 101.87 & 104.63 & 107.46 & 110.37 \\
Shortfall surplus & $(0.53)$ & $(0.30)$ & $(2.91)$ & $(3.43)$ & $(3.13)$ & $(4.22)$ & $(5.34)$ & $(6.51)$ \\
Food Import & 0.67 & 0.58 & 2.95 & 3.47 & 3.24 & 4.48 & 5.59 & 6.91 \\
\hline
\end{tabular}

Source: Federal Office of Statistics (2012), Review of the Nigeria Economy, Various Issues

Domestic food production is on the increase but not enough to meet national food demand. Demand remained higher than production and food imports keep increasing to augment the shortfall or deficit. Table 1 shows that Nigeria is a net food importer. If no meaningful strategy is put in place by government to stem the tide of food deficit, it may sooner than expected become too high to manage. Food production must grow consistently well above demand to bridge shortfalls.(Federal Office of Statistics, 2012).

Agricultural Performance in Foreign Exchange Earning

Table 2. Percentage Distribution of Nigeria's Export Earnings

\begin{tabular}{|l|l|l|l|l|}
\hline Period & $\begin{array}{l}\text { Proportion of oil to total } \\
\text { earnings export (\%) }\end{array}$ & $\begin{array}{l}\text { Proportion of Non-oil } \\
\text { to total Exports (\%) }\end{array}$ & $\begin{array}{l}\text { Average Agric } \\
\text { output growth }\end{array}$ & $\begin{array}{l}\text { Contribution of Agric } \\
\text { to real G.D.P(\%) }\end{array}$ \\
\hline $1960-1965$ & 11.8 & 88.2 & -1.9 & 31.1 \\
$1966-1970$ & 36.1 & 63.9 & -2.7 & 25.8 \\
$1971-1975$ & 85.1 & 14.9 & -3.5 & 35.0 \\
$1976-1980$ & 93.4 & 6.6 & -3.7 & 21.8 \\
$1981-1985$ & 97.4 & 2.6 & 14.3 & 30.6 \\
$1986-1990$ & 95.1 & 4.9 & 11.2 & 33.9 \\
$1991-1995$ & 97.2 & 2.8 & 7.4 & 33.6 \\
$1996-2000$ & 97.9 & 2.1 & 4.3 & 35.3 \\
$2001-2005$ & 94.5 & 5.5 & 2.7 & 41.0 \\
$2006-2010$ & 92.3 & 7.7 & 3.2 & 40.0 \\
$2011-2014$ & 93.0 & 7.0 & 2.6 & 38.0 \\
\hline
\end{tabular}

Source: Central Bank of Nigeria (2015).

Table 2 above shows the percentage distribution of Nigerian's export earnings from 1960 to 2014. The table shows that Nigeria's export earnings from non-oil products relative to oil products has never been in favour of Nigeria since the discovery of petroleum sector in early 1970s. Scholars argue that heavy reliance on crude oil as the major source of foreign exchange has been the major source of the economic problems in Nigeria (Okuneye, 2012). Similarly, contribution of agriculture to gross domestic products and average growth in agricultural output have been declining.Despite all the policy statements, the volume and value of non-oil export in Nigeria is yet to have any positive influence on the economy to justify the enormous efforts being expended on the sector. To reverse this ugly trend would possibly require adopting a strategic approach for marketing of agricultural products in Nigeria.

\section{Agricultural Performance in Labour Employment}

The number of people engaged in farming keeps decreasing in ways that will have profound effect on the Nigerian food marketing system. According to Ejionueme and Nebo (2014), the total number of farm family was roughly 12 million in 2003. This number has drastically been reduced to less than 4 million as at the end of 2012 .

Agricultural Performance in Raw Material Production

Research also show that raw materials requirements in foods, beverages and tobacco sector in Nigeria far exceed its supplies as at 2013. (Ejionueme and Nebo, 2014). 
Adopting Agricultural Marketing Approach for Improving Agricultural Sector Performance in Nigeria

\subsection{Relationship between Marketing and Agricultural Sector Performance in Nigeria}

There is a high level of linkage, interconnection and interrelationships between agriculture and marketing. Agricultural marketing complements agricultural production. Every agricultural produce must be sold immediately or presented for future sales or use after harvest. Agriculture cannot be complete without the effective marketing of its produce.Marketing move agricultural produce from areas of surplus to areas of deficit. Marketing makes it possible for some seasonal agricultural products to be consumed throughout the year by storage functions. Marketing transfers ownership of agricultural produce from the farmer to the consumers. It also changes agricultural products in ways desired by consumers by sorting, grading standardizations, packaging, processing and preservation functions. Agricultural marketing tells the users and buyers where and when to find the products and at what prices they are sold.Pricing which is regarded as a marketing function, guide and regulates production decision of farmers on what is to be produced. For example, farmers can switch from corn production to soybeans when the price ratio favours soybeans and vice versa. Ideally market conditions dictate farmers' operational plans in terms of what quantity to produce. Minten (1999) did a study titled "Infrastructure, Market Access andAgricultural Prices: Evidence from Madagascar and discovered that agricultural producer prices decrease significantly as the distance to main roads increases and the quality of infrastructure (market access) decreases. Similarly Kamara (2004), studied the Impact of Market Access on Agricultural Input Use and Productivity in Machakos District, Kenya and found that all inputs and agricultural productivityincreased with improvement in the access of farmers to output markets. He concluded that prioritizing the improvement of market access is an important approach to rural development as it gives farmers the opportunity to engage in more meaningful agricultural productivity. This means that marketing aids agricultural development.

\section{Methodology}

The study examined how agricultural marketing could be adopted for improving agricultural sector performance in Nigeria. Survey research designed was used in this study. A total of 250 agricultural marketers comprising farmers and middlemen were conveniently selected for study in the Eastern States of Nigeria. A structured questionnaire was used for data collection. The reliability of the research instrument was ascertained using Crombach's Alpha test. The reliability test showed that the instrument was internally consistent at 0.81 standard alpha using a benchmark reliability score of 0.70 (Nunnally and Bernstein, 1994). Principal Component andMultiple Linear Regression Analysis were used to test the hypotheses.

\section{Data Analysis And Findings}

Out of the 250 copies of questionnaire distributed, 218 (87.3\%) were returned and used for analysis.

\subsection{Test of Hypotheses}

\section{Hypothesis One}

$\mathrm{H}_{01}$ : Production, distribution and priceare not significant problems of agriculturalmarketing in Nigeria

$\mathrm{H}_{1}$ : Production, distribution and price are significant problems of agricultural marketing in Nigeria

To test this hypothesis, principal component Analysis (PCA) method of factor analysis was used.

The results are presented through Tables 3 and 4 below.

Table 3. Total Variance Explained

\begin{tabular}{|l|l|l|l|l|l|l|l|l|l|}
\hline \multirow{2}{*}{ Comp. } & \multicolumn{3}{|l|}{ Initial Eigenvalues } & \multicolumn{3}{l|}{ Extraction Sums of Squared Loadings } & \multicolumn{3}{l|}{ Rotation Sums of Squared Loadings } \\
\cline { 2 - 10 } & Total & \% of Var & Cum. \% & Total & \% of Var & Cum. \% & Total & \% of Var & Cum \% \\
\hline 1 & 27.128 & 71.389 & 71.389 & 27.128 & 71.389 & 71.389 & 16.164 & 42.536 & 42.536 \\
\hline 2 & 3.264 & 8.589 & 79.978 & 3.264 & 8.589 & 79.978 & 9.448 & 24.864 & 67.400 \\
\hline 3 & 2.003 & 5.272 & 85.250 & 2.003 & 5.272 & 85.250 & 2.493 & 6.562 & 73.962 \\
\hline 4 & 1.566 & 4.121 & 89.371 & 1.566 & 4.121 & 89.371 & 2.303 & 6.061 & 80.023 \\
\hline 5 & .886 & 2.332 & 91.703 & .886 & 2.332 & 91.703 & 1.378 & 3.626 & 83.649 \\
\hline 6 & .664 & 1.749 & 93.451 & .664 & 1.749 & 93.451 & 1.276 & 3.358 & 87.007 \\
\hline 7 & .409 & 1.077 & 94.528 & .409 & 1.077 & 94.528 & 1.119 & 2.944 & 89.951 \\
\hline 8 & .383 & 1.008 & 95.536 & .383 & 1.008 & 95.536 & 1.070 & 2.816 & 92.767 \\
\hline 9 & .293 & .770 & 96.306 & .293 & .770 & 96.306 & .629 & 1.656 & 94.424 \\
\hline 10 & .220 & .579 & 96.884 & .220 & .579 & 96.884 & .520 & 1.369 & 95.793 \\
\hline 11 & .194 & .512 & 97.396 & .194 & .512 & 97.396 & .261 & .686 & 96.478 \\
\hline 12 & .154 & .405 & 97.801 & .154 & .405 & 97.801 & .242 & .638 & 97.116 \\
\hline 13 & .115 & .304 & 98.104 & .115 & .304 & 98.104 & .144 & .379 & 97.495 \\
\hline 14 & .092 & .241 & 98.346 & .092 & .241 & 98.346 & .143 & .376 & 97.870 \\
\hline 15 & .074 & .196 & 98.541 & .074 & .196 & 98.541 & .129 & .340 & 98.211 \\
\hline 16 & .069 & .181 & 98.723 & .069 & .181 & 98.723 & .111 & .292 & 98.503 \\
\hline 17 & .061 & .159 & 98.882 & .061 & .159 & 98.882 & .090 & .237 & 98.740 \\
\hline 18 & .056 & .147 & 99.029 & .056 & .147 & 99.029 & .088 & .231 & 98.970 \\
\hline
\end{tabular}

DOI: $10.9790 / 487 \mathrm{X}-1904030417$

www.iosrjournals.org 
Adopting Agricultural Marketing Approach for Improving Agricultural Sector Performance in Nigeria

\begin{tabular}{|c|c|c|c|c|c|c|c|c|c|}
\hline 19 & .050 & .132 & 99.161 & .050 & .132 & 99.161 & .073 & .191 & 99.161 \\
\hline 20 & .044 & .116 & 99.277 & & & & & & \\
\hline 21 & .035 & .091 & 99.368 & & & & & & \\
\hline 22 & .034 & .088 & 99.457 & & & & & & \\
\hline 23 & .027 & .071 & 99.527 & & & & & & \\
\hline 24 & .025 & .065 & 99.592 & & & & & & \\
\hline 25 & .023 & .061 & 99.653 & & & & & & \\
\hline 26 & .021 & .054 & 99.708 & & & & & & \\
\hline 27 & .017 & .045 & 99.753 & & & & & & \\
\hline 28 & .017 & .044 & 99.796 & & & & & & \\
\hline 29 & .015 & .039 & 99.835 & & & & & & \\
\hline 30 & .013 & .034 & 99.869 & & & & & & \\
\hline 31 & .011 & .028 & 99.897 & & & & & & \\
\hline 32 & .008 & .022 & 99.919 & & & & & & \\
\hline 33 & .008 & .020 & 99.939 & & & & & & \\
\hline 34 & .007 & .019 & 99.958 & & & & & & \\
\hline 35 & .006 & .015 & 99.973 & & & & & & \\
\hline 36 & .005 & .013 & 99.986 & & & & & & \\
\hline 37 & .003 & .009 & 99.994 & & & & & & \\
\hline 38 & .002 & .006 & 100.000 & & & & & & \\
\hline
\end{tabular}

Table 3 above describes the total variables explained by the number of agricultural marketing problems components extracted. In all, 38 factors were studied,out of these 19 agricultural marketing problems components were extracted. These 19 components with Eigen-values greater than 0.5 altogether explain the variations among the problems affecting agricultural marketing in Nigeria by $99.16 \%$. These marketing problems components are identified through the component matrix on table 4 below.

Table 4 Related Component Matrix for Extracted Agricultural Marketing Problems.

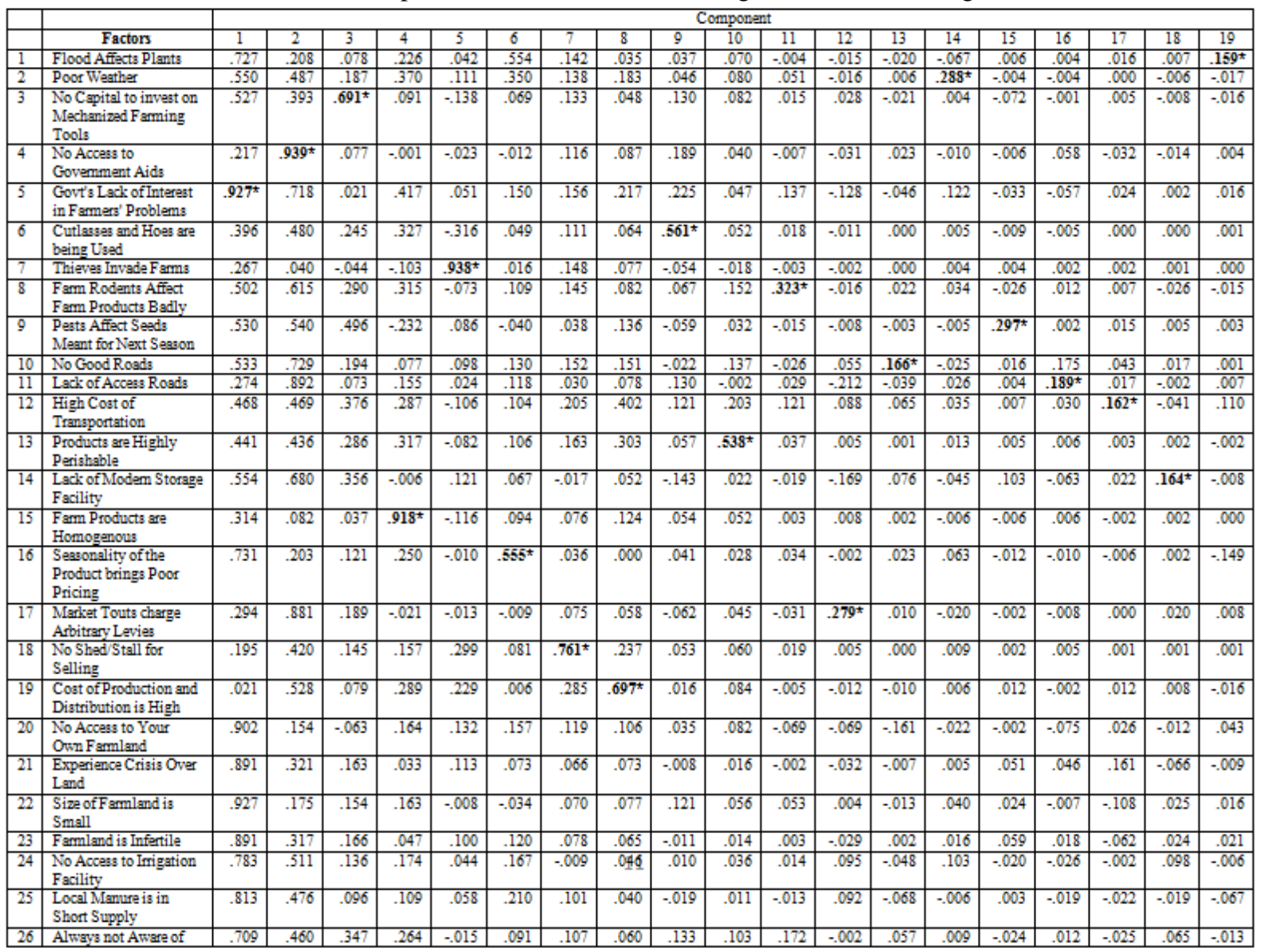




\begin{tabular}{|c|c|c|c|c|c|c|c|c|c|c|c|c|c|c|c|c|c|c|c|c|}
\hline & Govt. Grants and Aids & & & & & & & & & & & & & & & & & & & \\
\hline 27 & $\begin{array}{l}\text { No Access to Tractors } \\
\text { and Other Machineries }\end{array}$ & .695 & .502 & .182 & .260 & .037 & .054 & .144 & .135 & .101 & .187 & .225 & -.021 & -.037 & .011 & .055 & -.035 & -.020 & .079 & .039 \\
\hline 28 & $\begin{array}{l}\text { Lack of Knowledge on } \\
\text { How to Operate the } \\
\text { Machineries }\end{array}$ & .688 & .522 & .258 & .045 & .059 & .309 & .152 & .021 & -.094 & .058 & .023 & .057 & .028 & -.006 & -.012 & -.081 & .013 & .017 & .017 \\
\hline 29 & $\begin{array}{l}\text { Farm Pollutants from } \\
\text { Industry Waste }\end{array}$ & .827 & .255 & .366 & .148 & .002 & .029 & .083 & .053 & .194 & .059 & .042 & .028 & .018 & -.001 & .023 & .019 & -.060 & .035 & -.015 \\
\hline 30 & $\begin{array}{l}\text { Soil Erosion from } \\
\text { Heavy Rainfall }\end{array}$ & .601 & .502 & .505 & .162 & .001 & .202 & .174 & .115 & .057 & .067 & .009 & -.028 & -.003 & .038 & .045 & .023 & .028 & -.024 & .021 \\
\hline 31 & $\begin{array}{l}\text { Careless Set-up of Fire } \\
\text { around Famland }\end{array}$ & .920 & .162 & .131 & .171 & .132 & .050 & .038 & .030 & .177 & .049 & .015 & .015 & .077 & -.017 & .026 & .028 & -.058 & -.010 & .010 \\
\hline 32 & $\begin{array}{l}\text { Increased Conversion } \\
\text { Rate of F rmlands to } \\
\text { Buildings }\end{array}$ & .477 & .769 & .209 & .109 & .075 & .187 & .186 & .097 & -.033 & .063 & .025 & .161 & .012 & .035 & .013 & .005 & -.005 & -.008 & -.029 \\
\hline 33 & $\begin{array}{l}\text { Distance Covered to } \\
\text { Market is Long }\end{array}$ & .814 & .449 & .205 & .195 & .028 & .039 & .061 & .024 & -.030 & .075 & .070 & .053 & .116 & -.011 & .053 & -.018 & .027 & .038 & -.014 \\
\hline 34 & $\begin{array}{l}\text { Frequent Breakdown of } \\
\text { Vehicle }\end{array}$ & .925 & .162 & .102 & .154 & -.078 & -.090 & .085 & .092 & .054 & .059 & .046 & -.019 & -.093 & .060 & -.032 & -.050 & -.043 & -.141 & -.015 \\
\hline 35 & Drivers' Attitude & .773 & .368 & .376 & .156 & -.018 & .209 & .023 & .057 & .084 & .093 & .067 & .034 & .104 & .089 & .044 & .042 & -.013 & .009 & -.007 \\
\hline 36 & $\begin{array}{l}\text { Poor Lightening and } \\
\text { Power Supply }\end{array}$ & .882 & .306 & .121 & .028 & .246 & .046 & .037 & .042 & .045 & .049 & -.005 & -.003 & .034 & -.026 & .014 & .004 & .027 & -.005 & .019 \\
\hline 37 & $\begin{array}{l}\text { Grading/Standardization } \\
\text { is Hard }\end{array}$ & .832 & .424 & .152 & .054 & .079 & .207 & .142 & .040 & -.073 & .028 & .000 & .022 & -.058 & -.003 & -.009 & .093 & -.047 & -.032 & .005 \\
\hline 38 & $\begin{array}{l}\text { Most Times forced to } \\
\text { Sell at Market Prices }\end{array}$ & .786 & .426 & .303 & .135 & .055 & .140 & .008 & .048 & -.038 & .097 & .103 & -.011 & .135 & .038 & -.051 & .028 & -.038 & .082 & .000 \\
\hline
\end{tabular}

Extraction Method: Principal Component Analysis.

Rotation Method: Varimax with Kaiser Normalization.

a. Rotation converged in 12 iterations.

\section{Rotated Component Matrix}

The components extracted from the table 4 above are listed below;

Table 5. Extracted Principal Components

\section{Production -Related Problems}

1. Flood.

2. Poor Weather.

3. Lack of Capital.

4. No Access to Government Aids such as Fertilizer and Loans.

5. Lack of Interest in Farm Problems by Government.

6. Traditional Implement such as Cutlasses \& Hoes.

7. Invasion of Farms by Thieves.

8. Rodents Attacks.

9. Pests Damage.

\section{Distribution - Related Problems}

10. No Good Roads.

11. Lack of Access Roads.

12. High Cost of Transportation.

13. Lack of modern Storage Facilities.

14. Lack of Market Stalls for Selling.

\section{Price / Product-Related Problems}

15. Product Perishability.

16. Homogeneity of Products.

17. Seasonality of Products.

18. Market Tout Charges.

19. High Cost of Production \& Distribution.

From these group of factors, it can be deduced that the most significant problems affecting agricultural marketing in Nigeria are: (i) Production Problems (ii) Distribution Problems (iii) Price Problems. Based on the foregoing results and analysis, the null hypothesis $\left[\mathrm{H}_{01}\right]$ would be rejected while the alternate hypothesis $\left[\mathrm{H}_{1}\right]$ which states that Production, Distribution and Price significantproblems of agricultural marketing in Nigeria would be accepted.

\section{Hypothesis Two}

$\mathrm{H}_{02}$ : Product doesnot significantly influence agricultural sector performance in Nigeria

$\mathrm{H}_{2}$ : Product significantly influence agricultural sector performance in Nigeria 
Adopting Agricultural Marketing Approach for Improving Agricultural Sector Performance in Nigeria

To test this hypothesis, two sets of data were used. These include; data on products' variables and data on agricultural sector performance. Multiple regression analysis was used and the results of the test are presented below

Table 6: Model Summary

\begin{tabular}{|l|l|l|}
\hline $\mathrm{R}$ & 0.951 & $95.1 \%$ \\
\hline $\mathrm{R}^{2}$ & 0.905 & $90.5 \%$ \\
\hline Adj. $\mathrm{R}^{2}$ & 0.901 & $90.1 \%$ \\
\hline S.E & 0.2012 & \\
\hline F Change & 0 & \\
\hline
\end{tabular}

Table 7: ANOVA

\begin{tabular}{|l|l|l|l|l|l|l|}
\hline \multicolumn{2}{|l|}{ Model } & Sum of Squares & Df & Mean Square & F & $p$-value \\
\hline \multirow{3}{*}{1} & Regression & 38.221 & 4 & 9.555 & 236.027 & $.000^{\mathrm{a}}$ \\
\cline { 2 - 7 } & Residual & 4.008 & 99 & .040 & & \\
\cline { 2 - 7 } & Total & 42.228 & 103 & & & \\
\hline
\end{tabular}

a. Predictors: (Constant), Agricultural Products' Nature, Standardization and Grading, Product Quality, Branding and Packaging

b. Dependent Variable: Agricultural Sector Performance (i.eaverage percentage contribution of Agriculture to real GDP from 1960 -2014, see table 1)

Table 8: Coefficients

\begin{tabular}{|c|c|c|c|c|c|c|}
\hline \multirow{2}{*}{\multicolumn{2}{|c|}{ Model }} & \multicolumn{2}{|c|}{ Unstandardized Coefficients } & \multirow{2}{*}{$\begin{array}{l}\text { Standardized Coefficients } \\
\text { Beta }\end{array}$} & \multirow[b]{2}{*}{$\mathrm{T}$} & \multirow[b]{2}{*}{$p$-value } \\
\hline & & B & Std. Error & & & \\
\hline \multirow[t]{5}{*}{1} & (Constant) & .628 & .243 & & 2.582 & .011 \\
\hline & Agric Products' Nature & .148 & .067 & .264 & 2.214 & .029 \\
\hline & Standardization \& Grading & .131 & .077 & .211 & 1.707 & .091 \\
\hline & Product Quality & .456 & .068 & .354 & 6.689 & .000 \\
\hline & Branding and Packaging & .113 & .079 & .202 & 1.431 & .155 \\
\hline
\end{tabular}

Tables 6, 7 and 8 above present the results of the regression analysis ran to describe the interaction effect between product's variables and agricultural sector performance in Nigeria. Table 6 presents the model summary indicating the fit of the model at $\mathrm{R}=95.1 \%$. Also the coefficient of determination at $\mathrm{R}^{2}=90.5 \%$ for which the effect of the independent variables determines the dependent variable was described. The ANOVA result on Table 7 also describes the collective effect of the independent variables [i.e. product variables] on the agricultural sector performance. It shows that product has a significant $(\mathrm{F}=236.027, \mathrm{p}<0.05)$ effect on the agricultural sector performance in Nigeria. But nonetheless, the result on Table 8 reveals specifically the contributory effect of each independent variable on the dependent variable. It was shown that though, other product variables have effect on the agricultural sector performance but the quality of products constitute the major or the most significant product variable affecting the agricultural sector performance in Nigeria, followed by agricultural products' nature (perishability, bulkiness, homogeneity, unstandardized quality, volume unpredictability and seasonality)

Based on the result on Table 7 , the null hypothesis $\left[\mathrm{H}_{02}\right]$ would be rejected while the alternate hypothesis $\left[\mathrm{H}_{2}\right]$ which states that product significantly influence agricultural sector performance in Nigeria would be accepted.

\section{Hypothesis Three}

$\mathrm{H}_{03}$ : Distribution does not significantly influence agricultural sector performance in Nigeria

$\mathrm{H}_{3}$ : Distribution significantly influence agricultural sector performance in Nigeria

To test this hypothesis, two sets of data were used. These include; data on distribution variables and data on agricultural sector performance. Multiple regression analysis was used and the results of the test are presented below

Table 9: Model Summary

\begin{tabular}{|l|l|l|}
\hline $\mathrm{R}$ & 0.86 & $86.0 \%$ \\
\hline $\mathrm{R}^{2}$ & 0.74 & $74.0 \%$ \\
\hline Adj. $\mathrm{R}^{2}$ & 0.733 & $73.3 \%$ \\
\hline S.E & 0.58947 & \\
\hline F Change & 115.103 & \\
\hline
\end{tabular}

Table 10: ANOVA

\begin{tabular}{|l|l|l|l|l|l|l|}
\hline \multicolumn{2}{|l|}{ Model } & Sum of Squares & Df & Mean Square & F & p-value \\
\hline \multirow{2}{*}{1} & Regression & 79.992 & 2 & 39.996 & 115.103 & $.000^{\mathrm{a}}$ \\
\cline { 2 - 7 } & Residual & 28.146 & 81 & .347 & & \\
\hline
\end{tabular}




\begin{tabular}{|l|l|l|l|l|l|}
\hline & Total & 108.138 & 83 & & \\
\hline a. Predictors: (Constant), Storage, Transportation & \\
\hline \\
b. Dependent Variable: Agricultural Sector Performance \\
\hline
\end{tabular}

Table 11: Coefficients

\begin{tabular}{|c|c|c|c|c|c|c|}
\hline \multirow{2}{*}{\multicolumn{2}{|c|}{ Model }} & \multicolumn{2}{|c|}{ Unstandardized Coefficients } & \multirow{2}{*}{$\begin{array}{l}\text { Standardized } \\
\text { Coefficients } \\
\text { Beta } \\
\end{array}$} & \multirow[b]{2}{*}{$\mathrm{T}$} & \multirow[b]{2}{*}{$p$-value } \\
\hline & & B & Std. Error & & & \\
\hline \multirow[t]{3}{*}{1} & (Constant) & 1.307 & .293 & - & 4.466 & .000 \\
\hline & Transportation & .116 & .241 & .970 & .481 & .001 \\
\hline & Storage & 1.076 & .227 & .952 & 4.744 & .000 \\
\hline
\end{tabular}

Tables 9, 10, and 11 above present the results of the multiple linear regression analysis ran on hypothesis three. On table 9, the regression model is confirmed to be fit at $\mathrm{R}=86.0 \%$ while the coefficient of determination [i.e. the percentage extent to which the independent variables can explain the dependent variable] is given at $\mathrm{R}^{2}=$ $74.0 \%$. Table 11, shows the contributory effect of transportation and storage on the agricultural sector performance. Transportation has more effect on agricultural sector performance than storage. The ANOVA test result on table 10 therefore affirms that, distribution have a significant $(\mathrm{F}=115.103, \mathrm{p}<0.05)$ effect on the agricultural sector performance. Based on these results, the null hypothesis $\left[\mathrm{H}_{03}\right]$ would be rejected, while the alternate hypothesis $\left[\mathrm{H}_{3}\right]$ which states that Distribution significantly influence agricultural sector performance in Nigeria would be accepted.

\section{Hypothesis Four}

$\mathrm{H}_{04}$ : Price does not significantly influence agricultural sector performance in Nigeria

$\mathrm{H}_{04}$ : Price significantly influence agricultural sector performance in Nigeria

To test this hypothesis, two sets of data were used. These include; data on price and data on agricultural sector performance. Multiple regression analysis was used and the results of the test are presented below

Table 12: Model Summary

\begin{tabular}{|l|l|l|}
\hline $\mathrm{R}$ & 0.964 & $96.4 \%$ \\
\hline $\mathrm{R}^{2}$ & 0.928 & $92.8 \%$ \\
\hline Adj. $\mathrm{R}^{2}$ & 0.928 & $92.8 \%$ \\
\hline S.E & 0.2258 & \\
\hline F Change & 1672.8 & \\
\hline
\end{tabular}

Table 13: ANOVA

\begin{tabular}{|c|c|c|c|c|c|c|}
\hline \multicolumn{2}{|c|}{ Model } & Sum of Squares & Df & Mean Square & $\mathrm{F}$ & Sig. \\
\hline \multirow[t]{3}{*}{1} & Regression & 85.351 & 1 & 85.351 & 1672.885 & $.000^{\mathrm{a}}$ \\
\hline & Residual & 6.582 & 129 & .051 & & \\
\hline & Total & 91.932 & 130 & & & \\
\hline \multicolumn{7}{|c|}{ a. Predictors: (Constant), Price } \\
\hline \multicolumn{7}{|c|}{ b. Dependent Variable: Agricultural sector Performance } \\
\hline
\end{tabular}

Table 14: Coefficients

\begin{tabular}{|c|l|l|l|l|l|l|}
\hline \multirow{2}{*}{ Model } & \multicolumn{2}{|l|}{ Unstandardized Coefficients } & Standardized Coefficients & \multirow{3}{*}{ t } & \multirow{2}{*}{ Sig. } \\
\cline { 2 - 5 } & B & Std. Error & Beta & 9.969 & .000 \\
\hline \multirow{2}{*}{1} & (Constant) & .738 & .074 & & 40.901 & .000 \\
\cline { 2 - 5 } & Price & .763 & .019 & .964 & 4 \\
\hline \multicolumn{2}{|l|}{ a. Dependent Variable: Agricultural sector Performance }
\end{tabular}

Tables 12, 13, and 14 above present the results of the simple regression analysis ran on hypothesis four. In table 12 , the regression model is fit at $\mathrm{R}=96.4 \%$ while the coefficient of determination [i.e. the percentage extent to which the independent variable can explain the dependent variable] is given at $\mathrm{R}^{2}=92.8 \%$. Table 14 shows the contributory effect of price on agricultural sector performance indicating that, at any $1 \%$ change in the level of price, there would be an effect on the agricultural sector performance by $96.4 \%$. The ANOVA test result on table 13 therefore affirms that, price will have a significant $(F=1672.885, \mathrm{p}<0.05)$ influence on the level of agricultural sector performance. Based on these results, the null hypothesis $\left[\mathrm{H}_{04}\right]$ would be rejected, while the alternate hypothesis $\left[\mathrm{H}_{4}\right]$ which states that Price significantly influenceagricultural sector performance would be accepted. 
Adopting Agricultural Marketing Approach for Improving Agricultural Sector Performance in Nigeria

\subsection{Summary of Findings}

After data analysis, findings show that:

1. Production, distribution and price are significant problems influencing agricultural marketing in Nigeria. These problems include - flood; poor weather; insufficiency of capital; inaccessibility of government aids such as fertilizer, seedlings and loans; government's indifference to farmers' problems; lack of modern farm technology; thieves invasion of farms; farm rodents and pests attacks, bad road networks, lack of access roads, high cost of transportation and lack of modern storage and stall facilities, lack of control over prices as a result of homogeneity, perishability and seasonality nature of agricultural produce, arbitrary market tout charges and high cost of production and distribution.

2. Product has significant influence on agricultural sector performance in Nigeria

3. Distribution has significant influence on agricultural sector performance in Nigeria

4. Price has significant influence on agricultural sector performance in Nigeria

\section{Conclusion And Recommendations}

Nigeria agricultural sector has not been providing enough food, foreign exchange, raw materials, employment and income for the rural poor due to poor attention given to agricultural marketing problems. We recommend that government should specifically provide solutions to the significant marketing problems identified in this study which areproduction, distribution and price - related. In addition, since product, distribution and price have significant influence on the performance and marketing of agricultural sector in Nigeria, we recommend that government and other agricultural marketing participants such as farmers, processors, agents, wholesalers, retailers, exporters should pay attention to these marketing variables. Specifically, government and other agricultural marketing institutions should improve on the quality, natureand pricing of agricultural produce by engaging in effective standardization, grading, branding, packaging, processing of produce and also engage in efficient distribution using modern storage and transportation facilities in order to boost the performance of the agricultural sector in Nigeria.

\section{References}

[1]. Akpala, A. (1993), Management: An Introduction and Nigerian Perspectives, Enugu: Precision Printers and Publishers

[2]. Armstrong, G. and Kotler, P (2005), Marketing: An Introduction ( $7^{\text {th }}$ edition), Upper Saddle River New Jersey: Pearson Prentice Hall.

[3]. Austin, R.D. (1996), Measuring and Managing Performance in Organizations, New York, NY Dorset House Publishing Co.

[4]. Brown, C.P (2005), Primary Commodity Control, London: Oxford University

[5]. Central Bank of Nigeria (2015). Central Bank of Nigeria Annual Report and Accounts 2015, CBN: Lagos

[6]. Committee on Definition (1960), Marketing Definitions, A Glossary of Marketing Terms, Chicago: American Marketing Association.

[7]. Dayo, P; Nkonya, E., Pender, J., and Oni, O. A. (2009), Constraints to Increasing Agricultural Productivity in Nigeria: A Review, International Food Policy Research Institute, Nigeria Strategy Support Program (NSSP) Background Paper No. NSSP 006 September.

[8]. Dess, G. and Robinson, R.B. Jr., (1984), Measuring Organizational Performance in the Absence of Objectives Measures: The case of the Privately-Held Firm and Conglomerate Business Unit", Strategic Management Journal, 5, 265-73.

[9]. Ejionueme, N.G. and Nebo, G.N (2014), Perspective in Food Marketing System, Enugu: Immaculate Publications Ltd.

[10]. Ejionueme, N.G. and Nebo, G.N (2014), Understanding Agricultural Marketing, Enugu: Immaculate Publications Ltd.

[11]. FAOSTAT (2004). Online Statistics from the Food and Agriculture Organisation of the United Nations (FAO): http://apps.fao.org/

[12]. Federal Department of Agriculture (1988), The Nigerian Agricultural Policy.

[13]. Federal Department of Agriculture (2001), The Nigerian Agricultural Policy.

[14]. Federal Office of Statistics (2012), Federal Office of Statistics 2012, Review of the Nigeria Economy, Various Issues

[15]. Gordon-Ashworth, F (1984), International Commodity Control, New York: St. Martins Press.

[16]. [16] Kamara, A.B (2004), The Impact of Market Access on Input use and Agricultural Productivity: Evidence from Machakos District, Kenya. Agrekon Vol, 43, No 2, June.

[17]. Kohl, R.L and Uhl, J.N (2002), Marketing of Agricultural Products, $9^{\text {th }}$ edition, New Jersey: Macmillan Publishing Company.

[18]. Kotler, P. (1980), Marketing Management: Analysis, Planning and Control, Englewood Cliffs: Prentice Hall Inc.

[19]. LaLonde, B (1977). Distribution Logistics Grows in Importance for Marketers, But Faculty Acceptance Lags. Marketing News.

[20]. McDaniel, S.W and Hise, R.T (1984). Shaping the Marketing Curriculum: The CEO perspective. Journal of Marketing Education, Summer,27-32.

[21]. Minten, B. (1999), Infrastructure, Market Access and Agricultural Prices: Evidence from Madagascar: Market and Structural Studies Division, International Food Policy Research Institute, Washington, D.C. 20006 U.S.A.

[22]. Nebo, G.N. (2015), Marketing in Nigeria, $2^{\text {nd }}$ edition, Enugu: Immaculate Publications Ltd.

[23]. Nunnally, J. C. and Bernstein, L. H (1994), Psychometric Theory, (3 ${ }^{\text {rd }}$ ed,) New York: McGraw-Hill in lacobucci, D and Duhochek, A (2003), Advancing Alpha; Measuring Reliability with Confidence.Journal of Consumer Psychology, 12 (4), 478-487

[24]. Nwosu, B. O (2007), Management: An Introductory Survey, Owerri: CIDA Organizations.

[25]. Ojo, M. O (2001), Food Policy and Economic Development in Nigeria, Central Bank of Nigeria..

[26]. Okuneye, P.A. (2012), Rising Cost of Food Prices and Food Insecurity in Nigeria and Its Implication for Poverty Reduction, $C B N$ Economic and Financial Review, Vol. 39 No.4 
[27]. Okumadewa, F. (1997), "Poverty and Income in Nigeria -Measurements and Strategies for Reform," Paper Presented at the Vision 2010 Workshop, April, 1997, Abuja. Okuneye, P.A. (1995). Nigeria Agriculture on the Run. Refuse to move. University of Agriculture, Abeokuta Inaugural lecture Series No. 2 36p.

[28]. Onyeke, J.K. and Nebo, G.N (2012), Principles of Modern Marketing, $2^{\text {nd }}$ edition, Enugu: Precious and Queen Nigeria Ltd.

[29]. Pride, W.M and Ferrell, O.C (1995), Marketing, Basic Concepts and Decisions, $4^{\text {th }}$ ed., U.S.A: Houghton Mifflin Company.

[30]. Thirtle, C., L. Lin and J. Piesse (2003), The Impact of Research-led Agricultural Productivity Growth on Poverty Reduction in Africa, Asia and Latin America. World Development 31 (12): 1959-1976.

[31]. Timmer, P. (1988), The Agricultural Transformation. In: Chenery, H. and T.N. Srinivasan (eds) Handbook of Development Economics, Volume 1, North-Holland:

[32]. Ugwuanyi, W.N and Ugwuanyi, G.O (1999), Agricultural Financial Management and Food Marketing, Nsukka: Johnkens and Willy Publication Ltd.

[33]. Uturu, C.O (2002), Agricultural Marketing, Nkpor-Onitsha: Baset Printing and Publishing Ltd.

[34]. Venkatraman, N. and, Ramanujam, V., 1986, "Measurement of Business Performance in Strategy Research, Academy of Manage Review, 11, 801-14.

[35]. Zikmund, William and D'amico, Michael (1993), Marketing, $3^{\text {rd }}$ edition, New York: John Wiley and Sons. 